\title{
Effects of replacing groundnut cake with Gmelina arborea leaf meal in the diets of growing rabbits
}

A.A. Adeniji

Department of Animal Science, Faculty of Agriculture, University of Abuja, Nigeria.

\begin{abstract}
Seventy-two (72) grower rabbit were used to assess the replacement of groundnut cake with Gmelina arborea leaf meal in the diets of grower rabbits and determining its effect on growth; nitrogen digestibility and the economics of rabbit production. There were six (6) dietary treatments with Gmelina arborea leaf meal replacing groundnut cake at 0, 20, 40, 60, 80 and 100\%. Each treatment was replicated three (3) times with four (4) rabbits per replicate in a completely randomize blocked design (CRBD). Proximate analysis of Gmelina arborea leaves on air-cured basis showed that the leaves contained Dry Matter of 92.8, Crude Protein of 12.2, Crude Fibre of 24.88, Ether Extract of 2.18, Ash of 10.5 and Nitrogen Free Extract of 49.3\%; with a Metabolizable Energy of $480 \mathrm{Kcal} / \mathrm{g}$. Results showed that the final body weight, body weight gain and feed to gain ratio showed no significant difference $(P>0.05)$ between the treatments. The feed intake and cost of feed showed significant effect $(P<0.05)$ between the treatments. The cost of feed decreased as more Gmelina arborea leaf meal replaced groundnut cake in the diets. Profit, gross profitability and feed cost efficiency increased as more Gmelina arborea leaf meal replaced groundnut cake in the diets. The study revealed that Gmelina arborea leaf meal can be used to replace $60 \%$ of groundnut cake in the diets of grower rabbits.
\end{abstract}

Keywords: Grower rabbit, Groundnut cake, Gmelina arborea, growth, economics of production.

\section{Introduction}

The world is faced with inflation and problem of insufficient food production to sustain its ever-growing population. Generally, considerable attention is being given to food production, and more particularly livestock production. This is because animals play very important role in human nutrition as sources of protein. The demand for protein has risen greatly and the human dependence on animals for protein is increasing, especially since plant proteins are generally deficient in four essential amino acids; i.e. lysine, methionine, tryptophan and leucine. The daily animal's protein intake per head in developing countries like Nigeria has minimum requirement of $70.44 \mathrm{~g} /$ head/day by an adult human of this, at least $26-35 \mathrm{~g}$ should be of animal origin (Olorunfemi et al., 2009). If meat consumption demands are to be met, encouragement for the production of shortcycle animals like poultry and especially rabbits should be given great consideration by government and appropriate research institutes.

High cost and competition between man and animals for protein sources such as fish meal, making it expensive and scarce. Hence, the need to search for alternative protein source that are cheap, readily 
available and less competed for by man and industries (Akinmutimi, 2007).

Feed of rabbit is a very important aspect, given that the success of production depends on it. Rabbit is an herbivore and has a large capacity for forage consumption (Numbela and Valencia, 2003). Rabbit eat grass and herbaceous vegetation. They need a diet of less than $40 \%$ fibre, $10-20 \%$ protein for maintenance, and $14 \%$ protein for reproduction. Leaf meal of Gmelina arborea and other non conventional feeding materials are gaining acceptance as feed stuff in livestock diets, since they are locally available and not directly consumed by humans.

The plant is readily available in Nigeria. It is commonly called gmelina and white beach (English, Melina (Spanish), gamar in Bangladesh, Melina/gambar in India, gmelina in Indonesia, Yamane in Philippines and Soh in Thailand and it has many regional names (Brandis, 1906). It has seen planted less widely in tropical African and Latin American countries (Evans, 1982).

Since the plant is readily available, it will help to reduce cost of feed; therefore, this study was carried out to determine the level of groundnut cake which Gmelina arborea leaf meal can replace without causing any adverse effect on the rabbits.

\section{Materials and Methods}

Gmelina arborea leaves were harvested fresh, air-cured and then crumbled to produce Gmelina arborea leaf meal. Proximate analysis of the leaves was done according to the methods of A.O.A.C (1990). On analysis the leaves contained 12.2 crude protein, 28.8 crude fibre, ether extract and ash content were 2.1 and $10.5 \%$ respectively.
Six (6) experimental diets were formulated (Table 1). Diet 1 was designated to serve as the control with no Gmelina arborea leaf meal (GALM) inclusion. All other diets contain GALM replacing groundnut cake (GNC) at 20, 40, 60, 80 and 100\% respectively, with groundnut cake being $10 \%$ of the control diet. Diets formulated were iso-nitrogeneous. The rabbits were arranged into six (6) groups. The groups were assigned to the experimental diets using a Completely Randomized Block Design (CRBD). Each treatment was replicated three (3) times with four (4) rabbits per replicate. The study lasted for a period of eight (8) weeks.

The rabbits were housed in metal hutches with wire mesh at the base for easy passage of faeces and urine and raised above ground. The hutches were disinfected before the rabbits were introduced into the hutches. Their initial weight, final weight, feed intake values were recorded, and on the $8^{\text {th }}$ week, the faeces of the rabbits were collected by the total faecal collection method, analyzed and the nitrogen digestibility calculated. The market prices of feed ingredient during the experimental period were used for the for the economic appraisal of the diets. All data obtained were subjected to Analysis of Variance (ANOVA) using the Completely Randomized Block Design model as described by Steel and Torrie, (1980). Differences between means were separated using Duncan Multiple Range Test (Duncan, 1955).

\section{Results}

Growth performance of the grower rabbits fed different levels of GNC replaced with GALM is shown in Table 2 .

Final body weight showed no significant effect $(P>0.05)$ between the treatments. The rabbits fed $60 \%$ GALM had the highest 
Table 1: Composition of experimental diet $(\mathrm{kg} / 100 \mathrm{~kg})$

\begin{tabular}{|c|c|c|c|c|c|c|}
\hline \multicolumn{7}{|c|}{$\underline{\text { Levels of GALM \% (Control) }}$} \\
\hline In gredient & $\mathbf{0}$ & 20 & 40 & 60 & 80 & 100 \\
\hline GALM & 0 & 2 & 4 & 6 & 8 & 10 \\
\hline GNC & 10 & 8 & 6 & 4 & 2 & 0 \\
\hline Maize & 50 & 50 & 50 & 50 & 50 & 50 \\
\hline Fish meal & 0.5 & 0.5 & 0.5 & 0.5 & 0.5 & 0.5 \\
\hline $\mathrm{BDG}$ & 3 & 7 & 10 & 16 & 20 & 24 \\
\hline Corn bran & 19 & 11 & 14 & 6 & 9 & 8 \\
\hline Wheat offals & 12 & 16 & 10 & 10 & 5 & 2 \\
\hline Bone meal & 3.0 & 3.0 & 3.0 & 3.0 & 3.0 & 3.0 \\
\hline Limestone & 1.5 & 1.5 & 1.5 & 1.5 & 1.5 & 1.5 \\
\hline Salt & 0.35 & 0.35 & 0.35 & 0.35 & 0.35 & 0.35 \\
\hline Vit (premix) & 0.25 & 0.25 & 0.25 & 0.25 & 0.25 & 0.25 \\
\hline Methionine & 0.1 & 0.1 & 0.1 & 0.1 & 0.1 & 0.1 \\
\hline Lysine & 0.1 & 0.1 & 0.1 & 0.1 & 0.1 & 0.1 \\
\hline Coccidiostat & 0.2 & 0.2 & 0.2 & 0.2 & 0.2 & 0.2 \\
\hline Total & 100 & 100 & 100 & 100 & 100 & 100 \\
\hline M.E $((\mathrm{Kcal} / \mathrm{kg})$ & 2750.05 & 2748.05 & 2798.85 & 2770.85 & 2865.15 & 2908.25 \\
\hline \multicolumn{7}{|c|}{ Analyzed values of the experimental diets } \\
\hline Dry matter $(\%)$ & 88.4 & 88.0 & 88.12 & 87.04 & 89.02 & 89.88 \\
\hline Crude fibre (\%) & 4.82 & 5.11 & 4.85 & 6.10 & 6.22 & 6.02 \\
\hline Oil extract $(\%)$ & 5.10 & 4.90 & 4.80 & 4.60 & 4.50 & 4.40 \\
\hline NFE $(\%)$ & 47.00 & 56.61 & 50.15 & 5.14 & 46.83 & 50.68 \\
\hline Crude protein $(\%)$ & 14.44 & 14.41 & 14.37 & 14.44 & 14.38 & 14.21 \\
\hline $\mathrm{ASH}(\%)$ & 10.50 & 9.00 & 10.50 & 9.11 & 9.50 & 8.5 \\
\hline
\end{tabular}

Vitamin mineral premix contained: Vit A. 4000000IU; Vit. D3, 800000IU; Vit E. 10 IU, Vit $\mathrm{K}_{3}$, 1g; Vit. $\mathrm{B}_{1}$, $0.48 \mathrm{~g}$; Vit. $\mathrm{B}_{2}, 1.12 \mathrm{~g}$; Nicotinic acid, 6.4g; pantothenic acid, $1.6 \mathrm{~g}$; Vit. $\mathrm{B}_{6}, \mathrm{~B}_{12}, 6.4 \mathrm{~g}$; Folic acid, 0.16g; Biotin, 0.0112g; Vit. C 24g; Choline chloride, 4.8g; Zinc baritracin, 6.4g; manganese, 16g; Iron, 10g; Zinc, 6g; Copper, 0.32g; Iodine, $0.25 \mathrm{~g}$; Cobalt, $0.64 \mathrm{~g}$; and Selenium, $0.16 \mathrm{~g}$.

body weight gain of $12.94 \mathrm{~g}$ which was not statistically different $(P>0.05)$. The body weight gain values seemed to be gradually increasing from the control $(12.07 \mathrm{~g})$ to $60 \%$ GALM $(12.94 \mathrm{~g})$ but there after decreased for the rabbits fed 80 and 100\% GALM based diets. The rabbits fed on the 80 and $100 \%$ GALM had the lowest $(P>0.05)$ weight gain values of $9.35 \mathrm{~g}$ and $9.89 \mathrm{~g}$ respectively.

Table 2: Growth performance of rabbit fed Gmelina arborea leaf meal

\begin{tabular}{|c|c|c|c|c|c|c|c|c|}
\hline \multicolumn{9}{|c|}{ Level of Gmelina arborea Replacement for GNC (\%) } \\
\hline Parameters & 0 (control) & 20 & 40 & 60 & 80 & 100 & SEM & \\
\hline $\begin{array}{l}\text { Initial body weight } \\
\text { (g/rabbit) }\end{array}$ & 996 & 1,100 & 980 & 876 & 943 & 1020 & 30.69 & \\
\hline Final body weight ( $g /$ rabbit) & 1671.7 & 1798.0 & 1644.7 & 1600.7 & 1466.6 & 1574.1 & 48.98 & NS \\
\hline $\begin{array}{l}\text { Body weight gain } \\
\text { (g/rabbit/day) }\end{array}$ & 12.07 & 12.46 & 11.86 & 12.94 & 9.35 & 9.89 & 1.0 & NS \\
\hline Feed intake ( $\mathrm{g} /$ rabbit/day) & $94.6^{\mathrm{bc}}$ & $97.6^{\mathrm{a}}$ & $95.79^{\mathrm{b}}$ & $92.4^{\mathrm{c}}$ & $81.43^{\mathrm{d}}$ & $94.29^{\mathrm{bc}}$ & 2.36 & * \\
\hline Feed to gain ratio & 7.84 & 7.83 & 8.07 & 7.14 & 8.71 & 9.53 & 0.41 & NS \\
\hline Mortality & 0 & 0 & 0 & 0 & 0 & 0 & - & \\
\hline
\end{tabular}

*= Significantly different $(P<0.05)$

NS $=$ Significantly different $(P>0.05)$.

$\mathrm{a}, \mathrm{b}, \mathrm{c}, \mathrm{d}=$ Means with different superscript differs significantly $(P<0.05)$ 
Effects of replacing groundnut cake with Gm elina arborea leaf meal in the diets of growing rabbits

Table 3: Economic implication of feeding Gmelina arborea leaf meal to grower rabbit

\begin{tabular}{|c|c|c|c|c|c|c|c|}
\hline \multirow[b]{2}{*}{ Parameters } & \multicolumn{5}{|c|}{ Level of Gmelina arborea Replacement for GNC (\%) } & \multirow[b]{2}{*}{100} & \multirow[b]{2}{*}{ SEM } \\
\hline & 0 (control) & 20 & 40 & 60 & 80 & & \\
\hline Cost of feed $\mathrm{N} / \mathrm{kg}$ & $72.01^{\mathrm{a}}$ & $71.47^{\mathrm{ab}}$ & $69.29^{b}$ & $67.59^{\mathrm{c}}$ & $66.21^{\mathrm{c}}$ & $64.55^{\mathrm{d}}$ & $1.20^{*}$ \\
\hline Cost of feed consumed (N) & 286.11 & 292.97 & 278.77 & 262.30 & 226.44 & 255.63 & 9.96 \\
\hline Cost of rearing $\mathrm{N} /$ rabbit & 1086.11 & 1092.97 & 1078.77 & 1062.30 & 1026.44 & 1055.63 & 9.96 \\
\hline Selling price $(\mathbb{N} /$ rabbit $)$ & 1400 & 1400 & 1400 & 1400 & 1400 & 1400 & 9.96 \\
\hline Profit & 313.89 & 307.03 & 321.23 & 337.7 & 373.56 & 344.37 & 0 \\
\hline Gross profitability \% & 28.90 & 28.09 & 29.78 & 31.79 & 36.39 & 32.62 & 1.24 \\
\hline Feed cost efficiency & 0.40 & 0.39 & 0.42 & 0.47 & 0.55 & 0.51 & 0.03 \\
\hline
\end{tabular}

The feed intake values showed significant different $(P<0.05)$ between the treatments. The rabbits fed $20 \%$ GALM had the highest $(P<0.05)$ feed intake value of $97.6 \mathrm{~g}$ which was significantly different $(P<0.05)$ from the rabbits on other treatments. The lowest feed intake value of $81.43 \mathrm{~g}$ was recorded at $80 \%$ GALM.

There was no significant $(P>0.05)$ effect of the experimental diet on the feed to gain ratio obtained. The lowest feed to gain ratio was obtained on the rabbits fed $60 \%$ GALM diet; while the rabbits fed 100\% GALM have the highest feed to gain ratio value of 9.53. There was no mortality during the course of the experiment.

Table 3 shows the economic implications of feeding rabbits with GALM diets. The cost of feed $(\mathrm{N} / \mathrm{kg})$ showed significant difference $(P<0.05)$ between the treatments. It was observed that the feed cost ( $\mathrm{N}$ per $\mathrm{kg}$ ) decreased with the increase in the level of GALM in the experimental diet from $\mathrm{N} 72.01$ at $0 \%$ which was the highest to N64.55 at 100\% replacement which was the lowest cost of feed.

The cost of feed consumed was also significantly different $(P<0.05)$ between the treatments. Rabbits fed 20\% GALM showed the highest (N292.97) cost of feed consumed which was statistically comparable $(P<0.05)$ to rabbits on 0 and $40 \%$ GALM. Rabbits fed 80 and $100 \%$ GALM had the lowest cost of feed consumed.

The cost of rearing was also significant $(P<0.05)$ between the treatments. The highest cost of rearing (N1092.97) was recorded at $20 \%$ GALM diet while the lowest cost of rearing (N1026.44) was recorded at $80 \%$ GALM diet.

The Profit, Gross profitability and Feed cost efficiency showed the same trend as the highest and lowest values were recorded at 80 and 20\% GALM respectively. The highest profit, gross profitability and feed cost efficiency values of N373.56, N36.39 and 0.55 respectively were obtained at $80 \%$ GALM diet.

Table 4: Nitrogen digestibility of Gmelina arborea leaf meal fed rabbits

\begin{tabular}{|c|c|c|c|c|c|c|c|}
\hline \multirow[b]{2}{*}{ Parameters } & \multicolumn{6}{|c|}{ Level of Gmelina arborea Replacement for GNC (\%) } & \multirow[b]{2}{*}{ SEM } \\
\hline & 0 (control) & 20 & 40 & 60 & 80 & 100 & \\
\hline Nitrogen intake $(g)$ & 2.26 & 2.31 & 2.30 & 2.31 & 2.30 & 2.27 & $0.087^{\mathrm{NS}}$ \\
\hline Feacal nitrogen $(g)$ & 0.69 & 0.68 & 0.66 & 0.66 & 0.69 & 0.70 & $0.068^{\mathrm{NS}}$ \\
\hline Nitrogen retained $(\mathrm{g})$ & 1.59 & 1.65 & 1.64 & 1.65 & 1.61 & 1.57 & $0.014^{\mathrm{NS}}$ \\
\hline Nitrogen digestibility (\%) & 69.5 & 71.43 & 71.30 & 71.43 & 70.0 & 69.16 & $0.42^{\mathrm{NS}}$ \\
\hline
\end{tabular}


The nitrogen intake, faecal nitrogen and the nitrogen digestibility are shown in Table 4. The nitrogen intake did not vary significantly $(P>0.05)$ between the treatments. All the rabbits had comparable $(P>0.05)$ nitrogen intake. The values ranged between $2.26-2.31 \mathrm{~g}$. The faecal nitrogen also did not vary between the treatments. The faecal nitrogen between the treatments were comparable $(P>0.05)$. The values ranged between $0.66-0.68 \mathrm{~g}$. The nitrogen balance represents the difference between the nitrogen intake and the faecal nitrogen. The values showed no significant effect $(P>0.05)$. The values obtained were highly comparable. The experimental diets had no significant effect $(P>0.05)$ on the nitrogen digestibility of the grower rabbits, although this values were high in all the treatment.

\section{Discussion}

The difference in the feed intake value for different replacement level is generally acceptable and since no mortality was recorded indicates that GALM had no adverse effect on the rabbits.

There was significant difference in the feed intake between the treatments. This agrees with the findings of Yusuf et al. (2011). Rabbits can handle higher fibrous diets (Egbo et al., 2001) and the control and the $100 \%$ GALM had comparable feed intake value. The feed intake values of $81.43-$ $97.79 \mathrm{~g}$ recorded in this study were generally higher than the values $24.02-$ 60.54g reported by Eshiet et al. (1979) in the tropics and were however lower than the values $105.6-133.9 \mathrm{~g}$ reported by Ayers et al. (1996) when rabbits were feed in tropical condition.

Feed to gain ratio did not differ significantly $(P>0.05)$ between the treatments. This may be as a result of the low growth rates of the rabbits and also their genetic composition may be responsible for this. The values of $7.14-9.53$ recorded in this study were higher than $2.63-4.00$ reported by Ayers et al. (1996).

The cost of feed decreased with increase in the level of GALM replacing GNC, from the (control) $0-100 \%$. The cost of feed per $\mathrm{kg}$ showed significant difference $(P<0.05)$ between the treatment. This is understandable, since a low cost GALM was used to replace more quantity of a more expensive feedstuff (GNC). The high cost of GNC was as a result of it used as a convectional feedstuff and the low cost attributed to GALM was due to the fact that the plant is a forest waste and was cheaply harvested. This was in agreement with Adeniji et al. (2010) who reported that Gmelina arborea inclusion reduces the cost of feed per kg, but was conflicting with the report that there was increase in cost of feed per $\mathrm{kg}$ of the diets when Moringa oleifera leaf meal was used to replace Soybean meal in the diets of weaner rabbits (Nuhu, 2010). Gmelina arborea leaf meal has a nutrient profile similar to that of Chromolaena odorata leaf meal (Fasuyi et al., 2005) and that of the concentrate diet and thus can be used in formulating animal feed.

In conclusion, considering the effects of the diets on growth, economics and nitrogen digestibility showed that $60 \%$ GNC replaced with GALM gave the best result and is recommended as the best replacement level of GALM for GNC.

\section{Reference}

A.O.A.C 1990. Association of Official Analytical Chemists, Official methods of Analysis. 15th edition, Washington, D. C.

Adeniji, A.A., Gana, E.S., Chibuogwu, I.C. and Saria, M.O. 2010. The feeding value of Gmelina arborea leaves for growing rabbits. Proc. $36^{\text {th }}$ 
Ann. Conf., Nig. Soc. Animal Production (NSAP), March 13-16, 2011. University of Abuja, Nigeria, pp. 610-613.

Akinmutimi, A.H. 2007. Effect of cooking periods on the nutrient composition of velvet beans (Mucuna pruriens) Proc. $32^{\text {nd }}$ Annual Conference of Nigeria Soc. For Anim. Prod. (NSAP), University of Calabar, Calabar

Ayers, A.C., Barrett, R.P. and Cheeke, P.R. 1996. Feeding value of tree leaves (Hybrid Poplar and black locust) evaluated with sheep, goats and rabbits. Animal Feed Science Technology, 57: 51-52.

Biobaku, W.U. 1998. Growth response of rabbits fed graded level of groundnut shell: Effect on weight and enzyme activities. Journal of Pure and Applied Science. 1;44-50

Brandis E. 1906. PDF Assessment and preservation of tree diversity of Uttar Pradesh.

Duncan, D.B. 1955. Multiple range and Multiple F-test Biometrics. 11: 1-42.

Egbo, M.L., Doma, U.D. and Lacdaks, A.B. 2001. Characteristics of small scale rabbit production and management in Bauchi metropolis. Proceedings of the $26^{\text {th }}$ Annual Conference of Nigerian Society for Animal Production (NSAP), 18 - 21 March, 2001, ABU Zaria; pp 160 -162.

Eshiet, N.O., Omole, T.A. and Ademosun, A.M. 1979. The effect of feeding cassava root meal on the performance of fryer rabbits. Ife Journal of Agriculture, 2:2-6.

Evans, J. 1982. Plantation forestry in the tropics. Clarendon Press, Oxford UK $472 p$

Fasuyi, A.O., Fajemilehin, S.O.K. and Aro, S.O. 2005. Nutritional potentials of Siam weed (Chromolaena odorata) leaf meal (SWLM) on laying hens: Biochemical and haematological implications. Pakistan Journal of Nutrition 4(5): 336-341.

Nsa, E.E., Okon, B., Ozung, P.O., Akpan, I.A., Anya , M.A., Archibong, E.E., Edet, G.D. and Umoren, E.P. 2011. Response of rabbits to dietary levels of tiger nut (Cyperus esculentus). Proc. $36^{\text {th }}$ Conf. Nig. Soc for Anim. Prod. 13 - 16 March, 2011, University of Abuja, Nigeria pp. 290-291

Nuhu, F. 2010. Effect of Moringa leaf meal (MOLM) on nutrient digestibility, growth, carcass and blood indices of weaner rabbits. M.Sc. Thesis, Animal Science Department of the Faculty of Agriculture and Natural Resources/Kwame Nkrumah University of Science and Technology: Kumasi, Ghana.

Numbela, E.R. and Valencia, C.R. 2003. Guinea pig management manual. Benson Agriculture and Food Institute. Provo, UT, USA

Olorunfemi, F.A. Gbadegesin and Raheem, U. 2009. Climate change, urban vulnerability and disasters: A preliminary analysis of selected Nigerian cities. IOP Conf. Ser.: Earth Environ. Sci., 6: 562008-562008

Steel, R.G.D. and Torrie, J.H. 1980. Principles and procedures of statistics, Second Edition, New York: McGraw Hill

Yusuf, A.M., Amusa, T.D. and Olafadehan, O.A. 2011. Performance of grower rabbit fed diets containing raw, roasted and re-roasted Afzelia Africana seed meal. Proc. $36^{\text {th }}$ Ann. Conf., Nig. Soc. Animal Production (NSAP), March 13-16, 2011. University of Abuja, Nigeria. 284 286.

Received: $28^{\text {th }}$ March, 2011 Accepted: $28^{\text {th }}$ December, 2012 